\title{
Whose Authority May I Ask? Polish, English, German, Shakespearean or Directorial? On the Boundaries Between Ethnicity, Nationality, Religion and Theatricality in Jan Klata's Shakespearean Productions
}

\begin{abstract}
Jan Klata is a director who has been labelled a provocateur and who is considered to hold nothing cultural or national sacred. From the beginning of his artistic career he is said to have challenged authorities: theatrical, ethnic, national, etc. by debunking and questioning prevailing heroic myths and forms. Today, imperceptibly yet steadily, Klata himself becomes an authority and his theatrical productions gradually become classics in the eyes of the new generations of theatre directors and audiences, at the same time inciting and inevitably inviting cultural rebellion ... The article examines Klata's treatment of theatrical and national authority in his Shakespeare productions, on the one hand, and the image of the director as an authority on the other. All in the light of the theoretical model on authority in theatre, especially in Shakespeare productions, developed by W.B. Worthen.
\end{abstract}

Keywords: authority, authorship, performance, post-dramatic theatre, Shakespeare productions in Poland, Jan Klata

Any discussion of authority should begin at least with an authoritative definition. The Shorter Oxford English Dictionary gives, among others, the following understanding of authority: "II. Power to influence action, opinion, belief, etc.". It corresponds to W.B. Worthen's idea of "performance [which] is conceived as a collective means of knowledge making" (2014: 23). In other words, authority in today's theatre is at best aporic. Ever since the artistry and, indeed, auteur-ship (master control) of theatrical productions began to shift towards theatrical artists (actor-managers, directors, etc.), classical drama especially has lost at least some of its power. Naturally, the cultural context is very important. Questions asked in this respect may include: what constitutes 'classical drama' in a given culture, how is classical drama approached by

\footnotetext{
Adam Mickiewicz University in Poznań, Poland.
} 
theatre practitioners, critics, spectators and school canons in a given culture, what is the status of a 'classical author/playwright', what theatrical traditions does a given culture draw upon, etc.?

Magdalena Cieślak (2015: 68) makes us aware of one such cultural difference (also with reference to Shakespeare's plays). English-speaking, British theatre tends to be more 'logo-respectful' (but not logo-centric) in its approach to Shakespeare, the Bard, the canonical writer in the English-speaking world. For this reason, British theatre appears to be less experimental, in its nonpost-dramatic treatment of Shakespearean lines. Continental, or- to be more precise - Central European theatre is less bound by this respect of Shakespeare and often uses his texts as pretexts for the performance text. It is "dominated by 'Regietheater"' (Cieślak 2015: 68). Bradby and Williams (1988: 1) single out the role of the director in present-day theatre:

The dominant creative force in today's theatre is the director. No longer just an organiser, the director is now considered an artist in his or her own right... It is a distinguishing feature of directors' theatre that here the director claims the authorial function even though he has not written the original play. Where he is working with a classical text, he will rearrange, cut and rewrite to fit his production concept.

In such theatre the question of authority and auteur-ship becomes a genuine crux, even on the textual level, as it becomes what Lehmann refers to as postdramatic theatre, one in which the textual plane is composed of many different texts, not only of literary provenience but also cultural texts (music, film, lyrics, etc.).

The authority of performance has been extensively explored by W.B. Worthen's pioneering study, which focuses specifically on Shakespeare, the central figure in world theatre ${ }^{1}$ (let alone the English-speaking one), whose authority seems unquestioned, who-indeed-lends authority to theatrical productions. Worthen ponders on how much authority, in terms of identifying and recognizing the author and the ultimate control over production resides in theatrical work. Worthen appears to avoid essentialist positions and, instead, looks at the issue of authority as not only constructed, but as an ongoing process. According to Worthen (1997: 2), "[t]he relationship between texts, textuality, and performance is deeply inflected by notions of authority - not so much

1 Shakespeare has been appropriated by many cultures and nations; in Poland, this was done by Stanisław Wyspiański who, arguably, consolidated Shakespeare's position not only in theatre, but in Polish culture in general (although he did it at a time when Poland did not exist as an independent state). Wyspiański can also be held responsible for making Hamlet the Polish national play, and the figure of the hesitant Prince a symbol of Polishness. 
professional authority, but the stabilizing, hegemonic functioning of the Author in modern cultured production." (1997: 2), which makes Shakespeare such a towering figure in present-day culture in general, and in the theatre in particular, especially in view of the fact that Shakespeare is not just a Bard (a national poet for not only the English); he has been turned into a deity, thus ironically fulfilling Marlovian Faustus's dream. John Lennon said that God "is a concept by which we measure our pain." Shakespeare has reached such a position in contemporary culture, including theatre. His godlike status is underlined not only by generations of Shakespeare scholars, who may be said to venerate Shakespeare, but also by his vehement critics, indeed rebels or apostates (of the kind of Stephen Gosson), who-nevertheless-define themselves in opposition to Shakespeare.

Worthen (1997: 3) asks, in his study, important questions to which answers are extremely elusive: "I ask how authority arises in stage Shakespeare: in the role of the modern director, in the training and practice of actors, and in the interpretive practice of performance scholarships. How do directors, actors, and scholars represent the authority of Shakespeare in the action of performance?" He adds to this list of performance-related authority also the spectator: "the spectator [is] one of the agents of theatre ... a performer sustaining the signifying structure of the performance event, whose actshowever mute and motionless - frame, like the actor's, the event's significance" (2014: 23). Yet another agent of theatre are "technologies of performance" (2014: 23). The scholar thus distances himself from the prevailing dualism in the allocation of authority in the theatre, which he calls " $[\mathrm{t}] \mathrm{he}$ desire to ground the meaning of theatrical production by attributing it either to the authorial work or to the authorized institutions of stage practice" (1997: 6); the dualism echoes the eternal question that has haunted theatre scholars and can be best summarised in Beckett's words: "Astride of a grave and a difficult birth" (Beckett 1986: 84), the notion of the intermedial and inter-art nature of theatre, a servant of two masters, two authorities.

Naturally, in the case of Shakespeare, the notion of authority and auteurship was different in Elizabethan times than it is today. W.B. Worthen is well aware of the complexity of authorship in Early Modern English theatre: "[t]he conditions of production in the Renaissance playhouse militate against the final ascription of an ideal, coherent, work to a single animating author, and the texts of Shakespeare's plays are the result of dialogue and collaboration, of authorial and nonauthorial revision and of the demands of theatre practice" (1997: 8). The recent New Oxford Shakespeare volume edited by Gary Taylor, John Jowett, Terri Bourus and Gabriel Egan (Oxford University Press, 2016) is a good case in point, as it makes us aware of how many plays by Shakespeare were written in collaboration. The group effort in composing plays in the Renaissance is at length discussed in Jeffrey Masten's (1997: 1) article; the staging of the plays 
was yet another collective work. At the same time, however, playwrights and companies were celebrity-conscious: Ben Jonson not only quarrelled with Inigo Jones over the authorship of the masks they collaborated on, but proudly claimed in his "Prologue" to Volpone: "From his own hand, without a co-adjutor,/ Novince, journey-man, or tutor" (Jonson 1983: 13). Marlowe, in turn, made sure the audience recognised theatrical performances in his "Prologue" to Doctor Faustus:

Not marching in the fields of Trasimene

Where Mars did mate the Carthaginians,

Nor sporting in the dalliance of love

In courts of kings where state is overturned,

Nor in the pomp of proud audacious deeds,

Intends our muse to vaunt his heavenly verse.

(Doctor Faustus, "Prologue," 1-6)

Marlowe, however, never names himself as the author of the plays mentioned in the opening of the "Prologue." Rather, he paints theatrical scenes which the audience should (have) remember(ed), thus drawing the spectators' attention to theatrical company's achievements (yet without naming the company).

Shakespeare's (and other Elizabethans') works do pose another problem today. The question is: how genuine are they? We do not have access to manuscripts which bear the stamp of utter authority. We have differing editions of Shakespeare's plays, plays which he probably never authorised for print. As a result, from the modern perspective, "[t]he theatre might seem to be a fully nonauthoritative transmitting agent: using texts Shakespeare never fashioned (modern editions), personnel Shakespeare never knew (the director, actresses), theatres Shakespeare never imagined (modern technology, architectural and scenic conventions), and actors and audiences informed by 400 years of history, how can any production claim to stage an authoritative work of Shakespeare?" (Worthen 1997: 12).

Authority in theatre in general and Shakespeare productions in particular does not, however, capture all the nuances of the problem. Live performance arts, or performance, according to Worthen (2014: 1) "perhaps implies something more unstable than theatre, at least in the context of contemporary scholarly and disciplinary debate, leveraging a sense of the stage resistant to notions of authorial, literary, textual determination." Performance thus makes the issue of authority and auteur-ship even more diluted and complex. There are, nonetheless, some positive aspects of performance's blurring authority: "Shakespeare performance provides a powerful instrument for examining the intersection of dramatic writing, the institutions of theatre, and evolving ideologies of performance" (Worthen 2014: 1-2). Shakespeare appears to lend 
a helping hand to the analysis of performance studies today and how the dramatic text oscillates between reading and acting:

To seize Shakespeare performance today is to ask how Shakespeare has become an instrument for exploring the continually contested parameters of performance, the boundaries between writing and doing, between onstage and offstage acting, between literature, theatre, and other technologies of mediated performance. (Worthen 2014: 2)

Three aspects of Klata's work are particularly interesting when taking into account authority in performing Shakespeare:

1. Jan Klata is considered a controversial director, who does not hesitate to debunk and question Polish national myths and stereotypes.

2. He has consistently addressed such issues in his Shakespeare productions (from $H$. to Titus Andronicus to King Lear; I would also look at his Hamlet produced at the Bochum theatre since the production, too, contains references to Polish-ness).

3. Shakespeare's status, which in religious terms can be associated with the theatrical sacred is, for Klata, a forum to present the theatrical and cultural profane; as a result, Shakespeare's authority (and authorship) is radically challenged, yet not altogether rejected.

Visitations of authority in Klata's theatre in general and his Shakespeare productions in particular are not an easy issue to address. First, because Klata contends authority in general, he is deemed controversial, he embraces and challenges national and mythical authority, yet at the same time upholds the authority of theatre and Shakespeare, although even here he does not cease to be a rebel. Klata as a 'rebel with a Mohican on his head' (also called an 'Angry Young Man' of the Polish theatre) ${ }^{2}$ is no longer young, perhaps less angry (see his Lear), as he himself slowly yet gradually aspires to the position of authority, a respected (at least in some circles; others still contest him and his achievements) and an experienced director whose work has been widely acclaimed in Poland and abroad. As a result, Klata (no longer shocking with his hair-style rather unusual among 'serious' and mature theatrical directors) is looked up to as an intellectual, a theatrical guru, administering his spectators a therapy in which ghosts of authority of various sorts are evoked, referenced, rejected, modified, transformed into other forms of authority, etc. There is no denying that Klata has developed his own theatrical style and approach to drama and the stage, also visible in the productions based on Shakespeare's plays. So far he has directed Hamlet twice ( $H$. in Poland and Hamlet in Germany), Titus

2 http://www.tvn24.pl/kultura-styl,8/buntownik-z-irokezem-dyrektorem-starego-teatru, 261253.html posted on 27 June 2012; a note on Klata's becoming the manager and director of the prestigious Teatr Stary in Kraków (doa: 5 March 2016). 
Andronicus (a Polish-German joined production) and King Lear (exclusively Polish). ${ }^{3}$ He prepared those productions in four different theatres, with four different troupes: $H$. with the Teatr Wybrzeże in Gdańsk (2004), Hamlet with the Schausspielhaus in Bochum (2013), Titus Andronicus with the Teatr Polski in Wrocław and the Staatsschauspiel in Dresden (2012), and King Lear with the Teatr Stary ensemble in Kraków (2014). In other words, Klata has built his theatrical capital on an international basis, testing his theatrical ideas, his approach to Shakespeare, and his debunking of national myths and stereotypes outside Poland. This certainly is a mark of a director with status and considerable achievements. An authority: moral, theatrical and Shakespearean, too, whose voice is always worth listening to [cf. also his activity as a Tygodnik Powszechny columnist]. Klata's is a fundamentally intellectual theatre, rather than a ritualistic one: it contains distancing and alienating devices disconcerting the spectators, it is characterised by raising difficult and inconvenient questions and confronting the recipients with them, it often mixes high and low culture. The latter is visible, among others, in combining in his scripts lyrics of popular songs with Shakespearean lines (Klata also reaches for other, more canonical texts, as additions to the Shakespearean basis). Of course, this is a standard practice today; in post-dramatic theatre, classical drama is complemented by fragments of other texts - scripts thus become collages and patchworks of cultural references (a technique deployed also in the visual sphere).

Thus, Klata opens his $H$. with Hamlet and Horatio playing turbogolf in the Gdańsk shipyard, to the music and lyrics of "Seven Nation Army" by The White Stripes, which comments on Hamlet's coming back to his hometown (=Elsinore=the floor of the yard). It is also an example of Klata using the techniques of sampling and scratching, associated with what may today be considered part and parcel of popular culture - hip hop. ${ }^{4}$ In this way, Shakespeare's authority is framed in the pop-cultural context. Popular culture is also evoked in, for example, Klata's treatment of the greatest and most canonical soliloquy: the 'To be or not to be' speech, which in this production is not spoken by Hamlet; the Prince, together with Rosencrantz and Guildenstern organise a talent show, an equivalent of the American Idol, for the spectators to give the best recitation of the soliloquy (or its first lines). The three characters behave like jurors in the show, commenting on particular performances.

Klata presents the theatrical and cultural profane by further reflecting on the status of 'To be or not to be' in his Bochum Hamlet - here the delivery of the speech is inscribed into the mousetrap, in which, instead of the Players'

3 Jan Klata has recently added to this list productions of Macbeth (Moscow Art Theatre, 2016) and Measure for Measure (Prague Theatre Pod Palmovkou, 2018).

4 The Q Brothers and Chicago Shakespeare Theater presented an 'ad-rapted' Othello: The Remix at the Globe-to-Globe World Shakespeare Festival for the London 2012 Cultural Olympiad. 
performance of the Murder of Gonzago, one first sees Hamlet performing the soliloquy as if he were in a school reciting contest. Claudius finds this rendering most appropriate, an example of the proper respect one should have for these lines and, indirectly, Shakespeare's authority behind them. One may find this version the opposite of what we have in $H .:$ it is an epitome of traditional theatre. Not only is it given by Hamlet, it is also complete and has the appropriately high and respectable form. Interestingly enough, the recitation is contrasted by part two of the show-within: an example / sample of a modern performance, contemporary theatre: Hamlet, Rosencrantz and Guildenstern thrash about the stage, pouring paint on each other and pretending to urinate and defecate. This is rejected by Claudius, but appreciated by Gertrude, who has more understanding for modern art. Incidentally, Klata in this way mocks the practices of the modern German stage; in Poland, such a mockery may extend further onto the Polish epigones of the authority of the German theatre. It appears that the director may have also referenced the modern German stage in some scenes in Titus: significant is the scene when Tamora at her wedding ceremony with Saturninus is riding an ice block whereas Lavinia (a most innocent character in Shakespeare's play, a victim) just falls short of being a slut. Interestingly enough, although Lavinia is part of the Roman 'team', impersonated by German actors in the production, her role is performed (in German) by a Polish actress, Paulina Chapko.

The Bochum Hamlet does contain textual admixtures, too. This time Klata ends the production (in German) on a Polish note: Fortinbras delivers a fragment of the poem written by Zbigniew Herbert, Elegy of Fortinbras. It is not only a beautiful coda, but one that shows respect for the authority of Shakespeare's text as well. It does not 'improve' Shakespeare, but complements the poetic and theatrical texture.

Interpolations of texts are characteristic of Titus as well, for even more obvious reasons. The play, Shakespeare's mediocre achievement, has fascinated different theatre/drama artists-Friedrich Dürrenmatt and Heiner Müller-who re-wrote this drama. It comes as no surprise, then, that Klata puts in his script lines from the latter's play: Anatomy Titus, Fall of Rome, which comments, among others, on racial and ethnic stereotypes and prejudices. In this production, the director also employs words as images, shown on a screen at the back of the stage, thus highlighting the authority of the word in a world which is so much image-depending. The crisis of the Gutenberg universe is also made manifest in Hamlet: books are literally transformed into the grave of Ophelia, they no longer carry the wisdom of our world but are reduced to mere building blocks, objects which happen to be made of paper and print. As Urszula Kizelbach notes (2015: 155), "literally, books fell from the sky, and all characters walked on books, wallowed in books, books formed a landfill on the stage, even Ophelia's grave was made of books...". 
National and ethnic myths, identity and stereotypes, which constitute what may be called patriotic authority, also haunt Klata's productions, and no exception has been made by the director for Shakespeare. In $H$. the action is set in a special place - the Gdańsk shipyard, the cradle of the Solidarność movement and a very important symbol of modern, post-communist Poland. The shipyard, once buzzing with workers building ships, now looks derelict, verging on bankruptcy, empty. The place appears suitable not for HAMLET but $H$. only ... The choice of Shakespeare's tragedy in commenting on Polish-ness is by no means accidental and, as Klata himself openly acknowledges, references Stanisław Wyspiański's essay Studium o Hamlecie [Study of Hamlet]. Wyspiański appropriated Shakespeare's play for Polish culture as he found that it reflects Polish problems; for him, the most suitable place to perform the tragedy in Poland was another site-specific 'stage': the yard of the Wawel royal castle in Kraków, the seat of Polish kings of the powerful Jagiellonian dynasty. Klata replaces the castle with the shipyard, which - like the castle yard at leastis an empty space echoing the glorious past. This heroic past is further indicated in the production in the figure of the Ghost - a mounted hussar, who reminds the spectator of great Polish victories. There is a marked contrast between Old Hamlet as the hussar in armour from 'head to toe' and Hamlet wearing a white costume of a fencer, whose only weapon can be a property (sic!), a harmless foil.

Klata also engages in dialogue with Wyspiański on the nature of theatre. Wyspiański, in his study, expounds his grand vision of the theatre, for which a royal castle is by no means too esteemed and worthy. Klata clearly challenges Wyspiański's authority, proposing a humbler, less ritualistic and more spectatororiented concept of theatre. Incidentally, in Klata's vision, the greatest tragedy is reduced from Hamlet to $H$.

The director references his $H$. in the Bochum Hamlet. He employs Michat Czarnik, who played the Prince in $H$., in two roles: the Old Hamlet and Fortinbras. Furthermore, Czarnik wears the characteristic fencing costume from $H$. and holds in his hand a golf stick. In this way, the proud, heroic figure of the hussar is reduced to a mock-warrior, mock-knight, mock-king, a theatrical character, a ghost (the whitish fencing dress certainly emphasises this impression). On the other hand, Czarnik-as-Fortinbras is more convincing, more substantial, as it were, certainly more energetic, especially when he barges into Elsinore, holding the golf stick as if he had a machine gun and shouting in German: "Händehoch!" (Hands up!), followed by "Zawsze to chciałem powiedzieć" (I have always wanted to say this line!) in Polish. He refers here to the pop-cultural image of a Nazi soldier from numerous Polish films about the Second World War, the 'bad' German who stops or is about to shoot the 'good' Pole. Klata thus contributes to the discussion about Polish-German stereotypes, which he has explored in a more profound manner in Titus.

The German and Polish actors, cast as the civilized Romans and the savage and barbarous Goths respectively, are parodies of national stereotypes. 
Klata has the Romans wear tunics/shirts with prints of the German emperor in the characteristic spiked helmet (Pickelhaube), the symbol of a typical Kraut; or prints of well-known photographs from WWII showing a German soldier aiming at a woman holding a child, the burning tower of the royal castle in Warsaw in September 1939, Wehrmacht soldiers removing the border barrier on their way to invade Poland, etc. Klata asks questions about Polish national myths, the martyrdom of the Poles during the war (what about the Jews who are mentioned as the victimized other by Heiner Müller - a fragment containing this line is screened on the back wall of the stage at the end of the production), idealized image of the Polish nation as proud, fighting against all odds, freedom-loving, etc., a victim, never a perpetrator. This is a myth which was developed in the Romantic period.

Polish sanctities have become, too, the subject of Jan Klata's King Lear. It is most notably manifest in the decision to set the action of the production in Vatican, in the milieu of the Catholic church, an institution held in great esteem in Poland, a genuine authority. Although Klata distanced himself from associating the figure of Lear/the Pope with that the late Polish Pope John Paul II, he nevertheless did admit that he had been very much impressed by the dignity with which John Paul II was dying and did not avoid showing his old age and senility in a world dominated by the cult of youth and life. ${ }^{5}$ The late Jerzy Grałek (died 15 February 2016), who played Lear, managed to render this dignity - his body was already sick-ridden, fragile, yet his voice surprisingly powerful. He did ooze and command authority resulting from, among others, the rigid hierarchical structure and the two-thousand-year tradition of the Catholic Church. Naturally Klata presents Lear's daughters-turned-sons-turned-cardinals in a less respectable fashion, showing their pettiness. Cordelia is actually played by an actress (Jaśmina Polak), but her gender is a matter of theatrical convention rather than a comment on the place of women in the Church.

I would like to close with final note on authority and respect in Klata's theatrical Shakespeares. The director did not choose a contemporary translation of Shakespeare's original into Polish, preferring a rather old-fashioned $19^{\text {th }}$-century rendering by Leon Ulrich. The reason for selecting Ulrich's translation was that it was more serious, with fewer comic interpolations. ${ }^{6}$ Ultimately, then, Klata acknowledges Shakespearean authority and perpetuates it in his productions, invoking ghosts of the classical past and canon. At the same time, he invokes yet another authorial/authoritative ghost: that of the translator. In the case of

${ }^{5}$ Klata said about it in a meeting with the spectators after the performance of King Lear at the Gdańsk Shakespeare Theatre during the $19^{\text {th }}$ Shakespeare Festival in Gdańsk on $5^{\text {th }}$ August 2015.

${ }^{6}$ Klata explained his choice of the translation in a meeting with the spectators after the performance of King Lear at the Gdańsk Shakespeare Theatre during the $19^{\text {th }}$ Shakespeare Festival in Gdańsk on $5^{\text {th }}$ August 2015. 
non-English Shakespeares, the translator's position in terms of authorship ranks just next to that of the author. The director needs to mediate between, on the one hand, the translation and the original text, and - on the other - the available translations, which become the authoritative versions of the text.

\section{WORKS CITED}

"Buntownik z irokezem dyrektorem Starego Teatru" [A rebel with a Mohican is the manager of the Stary/Old/ Theatre]. 2012. http://www.tvn24.pl/kultura-styl,8/ buntownik-z-irokezem-dyrektorem-starego-teatru,261253.html doa: 5 March 2016.

Beckett, Samuel. 1986. "Waiting for Godot", in: The Complete Dramatic Works. London-Boston: faber and faber. 7-88.

Bradby, David and David Williams. 1988. Directors' Theatre. Houndmills: Macmillan.

Brown, Lesley (ed.) 1993. The New Shorter Oxford English Dictionary. Oxford: Clarendon Press.

Cieślak, Magdalena. 2015. ““... The Ruins of Europe in Back of Me.' Jan Klata's Shakespeare and the European Condition". Studia Anglica Posnaniensia 50/4. 67-77.

Jonson, Ben. 1983. "Volpone, or The Fox", in: J.M. Morrell (ed.) Four English Comedies of the $17^{\text {th }}$ and $18^{\text {th }}$ Centuries. Harmondsworth: Penguin Books. $11-129$.

Kizelbach, Urszula. 2015. "Review of Hamlet. Dir. Jan Klata. Gdańsk Shakespeare Theatre, Gdańsk, Poland. Was lessen Sie, mein Prinz? ... Bücher, Bücher, Bücher!'. Multicultural Shakespeare 12 (27). 155-159.

Lehmann, Hans-Thies. 2006. Postdramatic Theatre. Tr. by Karen Jürs-Munby. LondonNew York: Routledge.

Marlowe, Christopher. 2003. "Doctor Faustus", in: Frank Romany and Robert Lindsey (eds.) The Complete Plays. London: Penguin Books.

Masten, Jeffrey. 1997. "Playwrighting: Authorship and Collaboration", in: Cox, John D. and David Scott Kastan (eds.) A New History of Early English Drama. New York: Columbia University Press.

Taylor, Gary, John Jowett, Terri Bourus and Gabriel Egan (eds.) 2016. The New Oxford Shakespeare. The Complete Works. Modern Critical Edition. Oxford: Oxford University Press.

Worthen, W.B. 1997. Shakespeare and the Authority of Performance. Cambridge: Cambridge University Press.

Worthen, W.B. 2014. Shakespeare Performance Studies. Cambridge: Cambridge University Press.

Wyspiański, Stanisław. 2000. Hamlet [Study of Hamlet]. Gdańsk: Tower Press. 